was more pronounced in bacon pigs $(50-100 \mathrm{~kg}$ weight $)$ than in sows or boars, but mortality was low. Most of these breeding animals did not get ill. Nevertheless, fever, anorexia and sometimes abortion were noticed. An influenza virus $\mathbf{H S W}_{1} \mathbf{N}_{1}$ was isolated in many herds and seroconversion was general $(95$ p. 100). Economic losses differed from one herd to another in relation with respiratory diseases especially pneumonia. Many epidemiological factors were involved in the spreading of influenza and their role was discussed. Clinical and serological studies in the herds 6 months post-infection showed the persistence of viral activity in some of them. This situation is being investigated.

\title{
Urinary disorders in sow herds : diagnosis, consequences, environmental and physiological factors
}

\author{
F. MADEC, Françoise DAVID * \\ Ministère de l'Agriculture, Direction de la Qualité, Services vétérinaires \\ * Station de Pathologie porcine, B.P. 9, 22440 Ploufragan \\ France
}

Three studies were made (Brittany, France) on urinary disorders in sows detected in slaughter houses, in experimental production units and in conventional herds. Nitrites were found in 17 p. 100 of them. Cytobacteriological controls showed the presence of bacteria in $36 \mathrm{p}$. 100 of urines, but acute bacteriuria $\left(10^{6}\right.$ germs $\left./ \mathrm{ml}\right)$ was only found in $13 \mathrm{p} .100$ of the sows. It was more frequent in sows than in gilts. Most bacteria were of faecal origin with facultative pathogenic properties. A diagnosis scheme is suggested comparing the different methods of detection of urinary disorders. Furthermore, comparison of the environmental conditions in a hundred herds allowed to determine the main factors responsible for urinary infection : water intake, hygiene, constipation and sedentariness.

\section{Health control of breeding herds Role of the laboratory of pig pathology}

\author{
M. REYBAUD, J.C. BUARD *, Marylène KOBISCH **, J.P. TILLON ** \\ Coopérative Agricole de la Mayenne (C.A.M.), \\ 89, rue de Magenta, B.P. 731, 53002 Laval Cedex \\ *Vétérinaire-conseil à la C.A.M. \\ ** Ministère de l'Agriculture, Direction de la Qualité, Services vétérinaires, \\ Station de Pathologie porcine, Les Croix, 22440 Ploufragan
}

France

During the last twelve years a steady concentration of pig production units was observed in France (in the West and in a restricted number of farms) as well as an intensification and development of selection shemes and exchanges of breeding animals.

Health control programmes and methods for decision of breeding animal diffusion were suggested by several authors (J. Forest \& A. MAllite, 1979; P. VANNiER, M. Kobisch \& J.P. Tillon, 1980).

Health control programmes of both selection and multiplier herds applied since 1975 are reported here.

In the present article, we only mention the control or respiratory diseases. Using two examples we show the role of the laboratory in the decision of diffusion or no diffusion.

The following data were collected in herds A and B : clinical observations, slaughter examinations (snout sections, lungs), results of controls in 10-week-old piglets performed 